Est Ag 41 (2006) 433-457

\title{
En nombre de la justificación
}

El juego de palabras es inevitable: ¿tiene hoy día justificación la justificación?, ¿sigue siendo válida como causa principal de la división entre católicos y protestantes?

En sentido coloquial, todo mundo sabe lo que dicha palabra implica: justificar es dar razones donde no se perciben, "hacer que una cosa sea admisible" 1 . Cuando algo tiene justificación es que encierra cierta razón de ser en alguno de sus pliegues; mostrar alguien una actitud injustificable es tener una postura inaceptable desde cualquier ángulo que se mire; justificarse es explicar una acción propia a primera vista criticable. Sin embargo, en su sentido espiritual resulta un concepto extraño, no ya para el hombre medio, a quien le suena directamente a chino, sino también para el cristiano, en cuya tradición ha surgido esta voz, tal vez incluso para el protestante, donde se sustanció al máximo. Estas tipologías humanas se mezclan mortalmente con la increencia de nuestra era, de manera que todos tendrían que recurrir al diccionario para captar de un golpe la idea religiosa de la palabra: justificar es "hacer Dios justo a uno dándole la gracia"2.

Ambas acepciones, vulgar y religiosa, pueden comprenderse bien desde la etimología de la palabra, que ilustra su origen, evolución y constante ambigüedad. Alude literalmente tanto a "ajustar" o adecuar, con lo que justificar es arreglar o subsanar y justificación sugiere concesión o longanimidad, como a "ajusticiar" o condenar, evocando el rigor de la ley o la presencia insobornable de Dios y su juicio, ante lo que siempre nos encontraremos indignos. Se fluctúa entonces de un cabo al opuesto, se produce un laberinto semántico, un cortocircuito lingüístico.

La doctrina de la justificación ha sido la excusa -la justificación- de la separación institucional y choques sangrientos entre católicos y reformados durante nada menos que cinco siglos. Teniendo en cuenta que el evangelio dice que se conocerá a los cristianos por el amor que se tienen (Jn 13,35), y que ya los Credos primitivos proclaman fe "en la Iglesia santa, una y cató-

\footnotetext{
${ }^{1}$ M. SeCo, Diccionario del español actual, II, Madrid 1999, 2753.

2 REAl ACADEMIA ESPAÑOLA, Diccionario de la lengua española, II, Madrid 1992, 1216.
} 
lica"3, es para quedarse con la boca abierta. Hay algo en alguna parte del cristianismo que no ha funcionado.

\section{EMPEZAR POR EL FINAL}

El contrasentido entre el mensaje cristiano de fraternidad y el hecho de la división de las Iglesias comenzó a ser notado y expresado en el ámbito misionero protestante. La credibilidad del cristianismo quedaba seriamente impugnada donde el testimonio de la fe se hacía desde la rivalidad confesional. Se convocó así en los albores del siglo XX, en 1910, la primera Conferencia Misionera Mundial, en Edimburgo, que reunió a delegados del variado pelaje que presentaban las confesiones cristianas anglosajonas que trabajaban por el evangelio en las zonas del imperio británico o derivadas o commonwealth. Como éstos no tenían representación oficial, quedó excluida toda resolución doctrinal, pero fue el punto de partida para empezar esos caminos. Podrían ser considerados los padres del ecumenismo, los pioneros en el esfuerzo por la reunificación cristiana 4 .

La autosuficiencia de la Iglesia católica la puso al margen de estos trabajos iniciales. Veía en dichos tanteos "un error que minaría en sus bases el fundamento de la Iglesia católica", esto es, saberse la única Iglesia verdadera. Favorecerlos podría llevar al indiferentismo, lo mismo da una Iglesia que otra, o a la aceptación de falsedades, las que albergaban los otros. "Sólo hay un modo de promover la unidad de todos los cristianos, y es fomentar el regreso a la única y verdadera Iglesia de Cristo de los que infelizmente se separaron de ella"5. La cosa estaba clara: ellos se habían marchado, ellos debían volver. Ecumenismo auténtico significaba retorno de los descarriados.

Desde entonces hasta el Vaticano II llovió bastante. Colaboración entre luteranos y católicos contra el nazismo, creación del Consejo Ecuménico de las Iglesias, nueva teología católica dialogante y abierta al mundo, expansión de la increencia. Todo ello condujo a un estado de opinión del que se pudo concluir que "promover la restauración de la unidad entre todos los cristianos es uno de los principales propósitos del concilio ecuménico Vaticano II". Ya no se habla de retorno de los otros, sino de reconocer "la culpa de una y otra parte", pedir perdón y perdonar. La división "contradice abier-

\footnotetext{
3 DENZINGER-HÜNERMANN 5.

${ }^{4}$ Para la historia del movimiento ecuménico, C. O'DonNELL - S. PIÉ-NinOT, Diccionario de eclesiología, Madrid 2001 (voces sobre ecumenismo).

5 AAS 20, 1928, 7; 14.
} 
tamente la voluntad de Cristo, es un escándalo para el mundo y daña la causa santísima de la predicación del evangelio a todos los hombres"6.

Lloviendo un poco más, tras el concilio nos hemos encontrado con la paradoja de un insuperable ecumenismo retórico y un escaso resultado práctico. Prueba de ello son las anuales semanas de oración por la unidad de los cristianos, los organismos bilaterales, reuniones múltiples y documentos de acuerdo entre católicos y cada uno de los no católicos, la apertura papal a la revisión de las funciones de su ministerio en Ut unum sint (1995)... sin llegarse todavía a gran cosa unitaria tangible.

La guinda del pastel ecuménico - palabras sin hechos- podría ser su último logro, la Declaración conjunta sobre la doctrina de la justificación, firmada el 31 de octubre de 1999 entre luteranos y católicos en Augusta (Augsburg en alemán). Pero también pudiera ser algo así como la joya de la corona del ecumenismo auténtico, suelo y sustento de la marcha hacia una intercomunión eficaz. Al fin y al cabo, la justificación fue el sostén de la rebelión del siglo XVI, la doctrina que ahondó persistentemente la fosa entre protestantes y católicos, de la que Lutero declaró que "no se puede ceder un ápice ni hacer concesión alguna aunque perezcan el cielo y la tierra y todo lo que pueda perecer"7. La elección de Ausburgo para la firma tampoco es casual. La ciudad bávara fue el lugar donde se elaboró en 1530 la Confessio Augustana, el credo básico del protestantismo cuando se asentaba la Reforma; donde se firmó la paz tras la guerra entre católicos y luteranos, en 1555, que acabó en empate y sancionó la convivencia legal de ambas confesiones; y donde se entrevistaron tres veces en tres días Lutero y el cardenal Cayetano para intentar reconducir la crisis incipiente en 1518. Habría sido impagable presenciar estos encuentros por una rendija para observar a los protagonistas: en el primero, un pobre fraile asustado frente a un poderoso príncipe de la Iglesia; en el último, el legado pontificio estaría secretamente pasmado mientras el agustino trasudaba desgaste y dureza.

La Declaración conjunta ha sido el resultado de un largo camino de reuniones, esfuerzos y documentos de las comisiones interconfesionales luterano-católicas alentadas desde el inmediato posconcilio, como se manifiesta en las notas y fuentes que cita la Declaración. Es pues el fruto de tres décadas de trabajo ecuménico ${ }^{8}$. Las mesas de diálogo y documentos publicados mostraban un sorprendente grado de cercanía en el tema de la justificación.

\footnotetext{
6 Unitatis redintegratio $1 ; 3 ; 7$.

7 Artículos de Esmalcalda II,1.

8 Sobre el proceso, A. MAFFEIS (ed), Dossier sulla giustificazione. La Dichiarazione congiunta cattolico-luterana, commento e dibattito teologico, Brescia 2000.
} 
Pero todo parecía quedar en lo teológico y abstracto, en las buenas intenciones de teóricos y estudiosos, más bien alejados de la pastoral y la cotidianidad. Era imprescindible un empujón oficial de las Iglesias al consenso entrevisto. La Federación Luterana Mundial y el Consejo Pontificio para la Promoción de la Unidad de los Cristianos pensaron llegada la hora de un escrito común sobre la justificación.

Tras dos esquemas previos, en enero de 1997 pudo presentarse por fin a discusión pública la redacción definitiva de la Declaración lograda entre las dos partes ${ }^{9}$. Constaba de 44 párrafos -cada uno señalado numéricamente para agradecimiento de los citadores-, de los que los más enjundiosos serían la introducción, que señala que se ha llegado a una "comprensión común de la justificación", de modo que "las diferentes explicaciones que aún subsisten no dan ya motivo para condenas doctrinales" (n. 5), y la conclusión, que reitera que "resultan aceptables las diferencias de lenguaje, explicación teológica y matices que aún permanecen" (40), de modo que "la doctrina de las Iglesias luteranas expresada en la presente Declaración no incurre en las condenas del concilio de Trento, y las condenas de los escritos confesionales luteranos no afectan a la doctrina católica expresada en la presente Declaración" (41). Entremedias (13-39) se van repasando las formulaciones polémicas y divisorias (sola gratia y obras, santificación y justificación, etc) en graciosa dialéctica: "juntos creemos..." primero, para a continuación añadir "cuando los católicos dicen... quieren afirmar...", compensado con "cuando los luteranos subrayan... pretenden tan solo...", de modo que se corroboran prólogo y epílogo, la comprensión común con diferentes explicaciones. La cuestión es entonces cómo es que nos hemos dado cuenta tan tarde. Hegel debiera haber vivido antes que Lutero.

Sometida a debate entre las Iglesias, la gran mayoría de los sínodos de las Iglesias luteranas que conforman la Federación, un $80 \%$, aceptarán el documento, mientras la minoría restante lo rechazaba o ignoraba. Así, en junio de 1998 se publica la breve Resolución del Consejo de la Federación Luterana Mundial, aprobatoria del acuerdo logrado, dando cuenta del proceso interno llevado por ellos. Expone que aunque sus Iglesias han encontrado cierta dificultad en algunas, a su juicio, carencias de la Declaración (ni justificación como criterio principal, ni realidad pecadora del justificado, ni rebajamiento de las buenas obras), en conjunto se muestran satisfechos. Pero no debió de serles tan fácil. Pesos pesados de la teología luterana como Eberhard Jüngel, emérito de la universidad de Tubinga, habían ad-

\footnotetext{
9 Texto castellano en Ecclesia, 18.VII.1998, 26-34.
} 
vertido cierta traición al no recogerse claramente la justificación como criterio decisivo de la fe cristiana, y en enero del 98, a modo de lobby religioso, más de 200 profesores de facultades teológicas evangélicas habían firmado un escrito clamando contra la Declaración conjunta (como buenos protestantes), en la que no veían que se hubiera alcanzado nada positivo, sino todo lo contrario, pidiendo en consecuencia rechazarla ${ }^{10}$.

Sólo faltaba remachar el clavo desde la otra parte. Pues hablando del rey de Roma... La Congregación para la Doctrina de la Fe y el Consejo Pontificio para la Unidad de los Cristianos hacían pública la Respuesta de la Iglesia católica a la Declaración conjunta, también en junio de 1998, una semana después de la Resolución luterana, seguro que poco casualmente ${ }^{11}$. $\mathrm{Al}$ igual que en ésta, se felicitan cálidamente por la convergencia lograda (primer párrafo), pero insiste mucho más que en ella en los aspectos aún pendientes, proponiendo una serie de "puntualizaciones" sobre ello (todos los párrafos siguientes, que componen 8 números). En sustancia, las dificultades se refieren al simul iustus et peccator, la importancia criteriológica de la justificación y la pasividad en la cooperación con la gracia. Es decir, justo las mismas objeciones a que había aludido de pasada la Resolución lutera$n a$, pero ahora naturalmente al revés y bien realzadas. Afirmaba además que no todas las diferencias "que separan a católicos y luteranos en la doctrina acerca de la justificación son meras cuestiones de acentuación o lenguaje", dudando entonces de que las condenas de Trento ya no tuviesen efecto (n. 5). Y de propina insinuaba la ausencia de autoridad de la Federación Luterana Mundial sobre sus Iglesias (n. 6).

Pillarse los dedos con la tapa del piano no hubiera dolido más. La parte luterana sopesó que la Declaración conjunta, lograda trabajosamente, había quedado puesta en tela de juicio, que los anatemas tridentinos les seguían pesando sobre la cabeza (independientemente de si les importaba) y que así no podía firmarse oficialmente ninguna Declaración. Las más altas instancias católicas implicadas (el cardenal Ratzinger escribiendo en el Frankfurter Allgemeine Zeitung y una carta del presidente del Consejo Pontificio para la Unidad de los Cristianos al secretario de la Federación Luterana) intentaron quitar hierro valorando como más importante la ratificación del acuerdo (el primer párrafo de la Respuesta católica) que las puntualizaciones siguientes, tan sólo cuestiones que pedían una ulterior clarificación. Tras un año de pausa, dimes, diretes y desmentidos, las partes

10 Textos reunidos en MAFFEIS 57-66; 147-150; 151-168.

${ }^{11}$ Ecclesia, 18.VII.1998, 34-36. 
logran concordar el 11 de junio de 1999 un nuevo escrito, la Declaración oficial común ${ }^{12}$, con el solo objeto de disipar las dudas levantadas. Se refrendan las afirmaciones de la Declaración conjunta, casi jurando y perjurando que efectivamente se ha llegado a un consenso en lo fundamental y que los anatemas pasados no tienen validez, y se hacen votos, de todos modos, por la necesidad de continuar el diálogo para afrontar los flecos pendientes y "reconciliar" las diferencias; se incluye un Anexo para responder a las objeciones surgidas sin añadir nada nuevo (para no recomenzar otra vez las tratativas), que por fuerza resulta tautológico, un abrumador amontonamiento de citas de la Biblia y de la Declaración conjunta para cada cuestión disputada: concupiscencia, obras y criterio central de la fe vuelven a la palestra; y la Iglesia católica reconoce el estilo luterano de autoridad sinodal. Esto último había sido un golpe bajo: si la parte católica sospechaba de la tradición luterana por depender en exceso de las bases, la parte luterana podía haber dicho que la forma católica es meramente jerárquica, de nulo contacto con el pueblo.

Y así, por fin se desbloqueó el proceso, dándosele colofón oficial con las firmas solemnes de los presidentes y secretarios del Consejo Pontifico y la Federación Luterana, y una liturgia unitaria de acción de gracias en la iglesia de santa Ana, en Augusta, en octubre de ese mismo año.

\section{LA SUSTANCIA DE LA ESENCIA}

En toda esta discusión, tantas idas y venidas, tantas vueltas y revueltas... ¿son de alguna utilidad? -que dijo el poeta-. Todo tiene cierto tufo de bizantinismo. Fe y obras propenden a contraponerse cuando más bien debieran integrarse; justificación y santificación se separan, en sentido de "perdón" lo primero y "mejoramiento" lo segundo, cuando incluso literalmente son la misma cosa; concupiscencia y pecado original se deshilachan en las fronteras del absurdo; y el criterio fundamental podría ser más modesto y conformarse con ser simplemente un criterio cristiano (como antes del siglo XVI). Como asevera la Declaración conjunta, todo ello podía quedarse en diferencias de lenguaje, en distintas tradiciones teológicas que no obstaculizan la fe común ni debieran hacerlo respecto a una vivencia eclesial común. Pero ha resultado un bizantinismo trágico, han sucedido cosas que no podríamos ni imaginar, batallas atroces entre cristianos, cató-

12 Ecclesia, 13.XI.1999, 20-21 (pone fecha equivocada). 
licos ahorcados por la Reforma, protestantes abrasados por la santa Iglesia... todo se perderá como lágrimas en la lluvia -otro poeta-. Esto es, ¿puede pagarse tan alto precio por la defensa de la fe auténtica? ¿No es el mensaje cristiano sólo una alegre invitación? La modernidad y secularización actuales parecen arrumbar este pasado al museo de los horrores y ponernos en nuestro sitio. Nos queda el consuelo de que las guerras cristianas se han debido más al deseo de poder que a la fe, ésta en realidad sólo un pretexto.

Las Iglesias saben que la doctrina de la justificación se ha vuelto hoy día irrelevante, desdibujada en la neblina metafísica. Da la impresión de que si con la justificación se mantiene o derrumba la Iglesia ya podemos ir salvando los muebles. Su recuperación y dignificación tendría que ajustarse sobre dos pivotes, como ambas partes admiten. Uno sería acudir a las fuentes de la revelación (centradas en la Escritura) con los instrumentos científicos de estudio que hoy poseemos (la crítica histórico-literaria), más allá de circunstancias históricas e interpretaciones subjetivas ${ }^{13}$. El otro incidiría en hallar un encuadre moderno para su plena inteligibilidad: "debería constituir una preocupación común de luteranos y católicos la búsqueda de un lenguaje capaz de hacer la doctrina de la justificación más comprensible también para los hombres de nuestro tiempo"14.

\section{La gracia motriz}

Cuado los filósofos se vuelven poetas, la justicia no sólo les parece la virtud principal, sino que la ensalzan además como la más hermosa: "ni el atardecer ni la aurora son tan maravillosos"15. Ahora bien, ¿qué es justicia? Todos tenemos una idea de ella, pero a la hora de definirla nos encontramos más bien perdidos. Tal vez la etimología sea el camino más corto para alcanzar su sentido ${ }^{16}$.

Tanto en griego (dikaiosúne) como en latín (iustitia) tiene que ver con ley (díke, ius), siendo entonces algo así como legalidad. Con todo, la legalidad, el derecho, es lo que compone las normas sociales comunes, intenta sencillamente la convivencia pacífica, pero no parece poder evitar leyes

13 Declaración conjunta 13; Respuesta católica 7.

14 Respuesta católica 8; también, Declaración oficial común 3.

15 Aristóteles, Ética a Nicómaco 1129 b25.

16 Para lo que sigue, G. ScHRENK, díke, díkaios, dikaiosúne, dikaióo: G. Kittel (ed), Theologisches Wörterbuch zum Neuen Testament, II, Stuttgart 1935, 180-223; K. KERTELGE, dikaiosúne, dikaióo: H. Baltz - G. Schneider (eds), Diccionario exegético del Nuevo Testamento, I, Salamanca 1996, 985-1013. 
negativas, injustas, para algunos individuos en algunos casos. Lo legal no siempre es justo. Así que una noción de justicia debe abrazar igualmente el bien, de modo que quede determinada como "dar a cada uno lo que se le debe"17. Justicia tendería entonces a indicar lo ideal, el comportamiento ejemplar, algo que va más allá de la ley estricta, lo legal, incluso más allá de la intención de la ley, lo legítimo. (En la reciente guerra de Iraq de 2003, los grupos críticos tachaban la intervención occidental de ilegal, ilegítima e injusta.) De aquí provendrán especificaciones ulteriores de la justicia, la justicia distributiva o igualdad, en cuanto a cada hombre se debe básicamente lo mismo, y la justicia retributiva o sanción, por cuanto conviene alentar o disuadir la conformidad o no a la ley.

En suma, tomada en sentido general, justicia señala la correspondencia de algo con lo que debiera ser, con la naturaleza de la cosa, o con lo legislado, lo organizado humanamente. De este modo sucede efectivamente en el lenguaje ordinario, donde "lo justo" incluye a la vez lo riguroso y lo modélico, así como "la justicia" abarca tanto los estamentos jurídicos como la perfección ética. El concepto de justicia se mueve, pues, en la convergencia de la legalidad y la moralidad, de la convivencia y la conciencia, es el río que toma el caudal de los dos afluentes. Esta dualidad la encontraremos constantemente, llevando a veces a equívocos. En clase nos preguntaban de pequeños a quién se refería lo de "bienaventurados los perseguidos por la justicia" (Mt 5,20), si a los bandidos o a los buenos. Y más en serio, la evolución semántica de justificación, iustum facere, ha señalado tanto "hacer justo", purificar, considerar correcto; como "hacer justicia", retribuir a uno estrictamente como merece, deviniendo en este sentido condenar ${ }^{18}$. Tendríamos aquí el principio de todos los males, pues la misma palabra puede interpretarse de un modo y del contrario.

En cuanto a la justicia aplicada a Dios, adoptará un contenido eminente a partir de la experiencia creada, como no puede ser de otro modo. Primeramente indicará la realidad de Dios siempre coherente con su ser. Y para el Antiguo Testamento Dios es sobre todo salvación, como lo expresa por ejemplo la revelación de su nombre. En las culturas antiguas, como en los motes de nuestras aldeas, los nombres propios no son sólo algo indicativo, sino más bien descriptivo, definen lo denominado: "Eva" (Gn 3,20), "Pedro" (Mt 16,18), "Toro Sentado", Manolo "Feo". El nombre toca la cualidad principal, la esencia, por así decirlo, de lo nombrado. Por eso el ju-

\footnotetext{
17 Platón, República 331e; 505a.

18 F.A. COMMELERAN, Diccionario clásico-etimológico latino-español, Madrid 1907, 728; también SCHRENK II,215.
} 
daísmo renunció a pronunciar el nombre de Dios, en respeto a su trascendencia inasible. Pues bien, el nombre de Dios, Yhwh (Ex 3,14), siguiendo la mentalidad dinámica semita y el contexto liberador en que surge, quiere decir "el que está al lado", el que asiste19. La justicia de Dios es la fidelidad de Dios a sí mismo, la donación salvífica que Él es. Embargada por esta emoción, la fe israelita sabe también destilar poética esperanzada: "ábrase la tierra y produzca salvación, y germine juntamente la justicia" (Is 45,8).

En segundo lugar, la justicia de Dios se refiere también a su enjuiciamiento sobre la conducta humana, si ésta se rige o no según sus mandatos, el ideal supremo de comportamiento (Sal 98,9). Aquí se advierte enseguida un desequilibrio: a la bondad de Dios no corresponde la lealtad humana. Tal es la denuncia recurrente de los profetas (Is 1; Jer 2). De la justicia de Dios, a fuer de perfecta, parece derivar la inevitable condena de los hombres.

Pero entonces, ¿no hay una contradicción entre la fatalidad reprobatoria de la justicia de Dios, de un lado, y su significado fundamental soteriológico, de otro, que hace de Dios sinónimo de salvación? Esta cuestión es el comienzo de la Carta a los Romanos, la primera dogmática de la fe cristiana $^{20}$. Para empezar, Pablo radicaliza el problema, pues rechaza de plano la petulancia farisea de poder cumplir la Ley, la Ley sólo sirve como patente de la postración humana, muestra simplemente que no se puede cumplir (Rm 7,7ss). Pero Pablo desveló la clave ya barruntada en el Antiguo Testamento (Jer 31,33s; Ez 36,26s): la justicia salvífica de Dios es superior a su justicia retributiva, en Cristo se nos ha señalado el paso de la enervante justicia de la Ley a la dadivosa justicia de la fe, "la justicia que viene de Dios" (Flp 3,9). La salvación se decide sólo en la confianza en Dios a través de Cristo, no puede ganarse.

Si justicia vale en la Escritura particularmente por salvación, justificar se referirá a aplicar la salvación, valorar como justo. Así sucede en Pablo, quien más usa el término y sus derivados, para el que significa en general absolver (1Cor 4,4). Dado que Pablo parte de la condición pecadora de todo hombre, la justificación sólo puede ser posible por una declaración favorable unilateral de Dios, cosa expresada en la redención de Jesucristo. De este modo, Pablo suele utilizar el verbo en voz pasiva, los hombres "son justificados" (Rm 3,23s), insistiendo en su peculiaridad de gracia indebida, como "justificación del impío" $(4,5)$. La necesaria y única participación de la libertad humana en la justificación divina es la fe, la acogida de la salva-

19 H. KÜNG, ¿Existe Dios?, Madrid 1979, 845ss.

${ }^{20}$ Sobre esto, U. WILCKENS, La carta a los romanos, I, Salamanca 1989. 
ción divina manifestada en Cristo. Las obras que crean merecer la salvación son un absurdo.

Verdaderamente, la justicia humana ante Dios es una incongruencia. Pensar y actuar son dos caras de la misma moneda, según concuerdan tanto filósofos antiguos como psicólogos modernos ${ }^{21}$, y del mismo modo que la inteligencia humana no puede comprender la inmensidad divina, la parte abarcar el todo, tampoco la voluntad del hombre puede conseguir a Dios, acreer por sus acciones la salvación. La salvación es comunicación, entrega del amor de Dios, algo inaccesible a la decisión humana, factible simplemente desde la misericordia divina. Así que decir justicia de Dios, justificación y por tanto salvación de Dios, es lo mismo que hablar de su gracia.

La gracia es un concepto a la par sencillo y enrevesado, una evidencia de la fe y un complejo tratado de dogmática ${ }^{22}$. Alude primeramente a lo que gusta, proviniendo de gratus (agradable) y éste de khaíro (alegrar), pasando a tener acepción de "encanto", si se trata de un don natural, o "favor", si se habla de relaciones humanas, que implica desinterés en quien lo concede y reconocimiento en quien lo recibe. Desde el punto de vista cristiano, prosiguiendo la religiosidad judaica, gracia se identifica inmediatamente con Dios: Él actúa como Padre cariñoso (Mt 7,9-11) y su presencia es una buena noticia (Mc 1,15). Pablo utiliza esa palabra profusamente para repetir que Dios es la misma gracia, el don de la justificación revelada en Cristo (Gál 2,21; 2Cor 6,1s), que el evangelio fructifica "desde el día en que oísteis y conocisteis la gracia de Dios" (Col 1,5s).

Ahora bien, esta gracia de la salvación es ofrecimiento, no sustituye la libertad humana, sino que la interpela. Pero creída y sentida en su generosidad inconmensurable -la experiencia de fe, la conmoción de saberse amado por Dios, objeto de su bondad inmerecida- resulta un obsequio tan exultante que no puede dejar de trasmutarse en impulso, de mover a quien lo vive en la misma dirección: quien se percibe querido y aceptado gratuitamente no puede dejar de volcarse gratuitamente. La gracia de Dios es eficaz por definición.

Un recuerdo de mi infancia tardía. A finales de los 60 apareció en casa el televisor, un aparato reverenciado que destellaba imágenes vivas y grises,

21 "Deseamos algo porque lo juzgamos bueno" (ARISTÓTELES, Metafísica 1072a25). "La lógica es una moral del pensar, así como la moral es una lógica de la acción” (J. PIAGET, El juicio moral en el niño, Madrid 1935, 391).

22 Sobre el particular, H. ConzelmanN - W. Zimmerli, Kháris: G. Kittel (ed), Theologisches Wörterbuch zum Neuen Testament, IX, Stuttgart 1973, 363-393; J.L. RuIZ DE LA PEÑA, El don de Dios. Antropología teológica especial, Santander 1991; L.F. LADARIA, Teología del pecado original y de la gracia, Madrid 1993. 
que conectaba con la capital, con toros y fútbol, con el Oeste americano. Los anuncios publicitarios eran otra maravilla comunicadora. Había uno que abordaba el naciente caos circulatorio urbano. Aparecía un conductor cada vez más impaciente esperando en una calle secundaria poder entrar en el flujo de la avenida, tan continuo que le impedía siquiera intentarlo. En éstas, en trance de desquiciamiento, llega otro conductor por la calle principal que frena ante él y le facilita el paso sonriente. Nuestro hombre se lo agradece con una leve inclinación de cabeza, entre sorprendido y aliviado, al tiempo que se incorpora al proceloso tráfico. Ahora conduce relajado, tarareando algo, cuando encuentra a un peatón ante un paso de cebra sin decidirse a cruzar porque los vehículos aceleran a su altura, dando un paso adelante y otro atrás angustiado. Entonces detiene su coche, cortando la marcha a los que vienen detrás, e invita a pasar al peatón cortésmente. El anuncio seguía entonces al peatón, caminando con aire sereno, que se topa con una viejecita al borde de la acera mirando a la otra parte con desaliento, el solo rugido de los coches la paraliza. Así que la coge del brazo y se ofrece a ayudarla levantando el otro brazo hacia los coches y cruzando lentamente con ella la calle... El anuncio terminaba diciendo: "sea amable, las cosas cambiarán". Me temo que no debió de tener mucho éxito circulatorio, pero relataba una experiencia universal: el amor es contagioso, bonum diffusivum sui.

De manera que la gracia es eficaz, saberse amado lleva a amar, la fe y las obras no se contradicen para nada. Pablo, con toda su insistencia en la justificación por la sola fe, no deja de remachar que ésta "actúa por la caridad" (Gál 5,6), sin la cual "nada vale una fe que traslade montañas" (1Cor $13,2)$. Santiago, tan preocupado por defender la necesidad de las obras que parece decir exactamente lo contrario de Pablo (St 2,24), lo que de verdad quiere destacar es que éstas "demuestran la fe" $(2,18)$. En realidad no se oponen tanto, simplemente parten de distinto cabo: la fe auténtica, la convicción, empuja a actuar en conformidad, y un obrar determinado refleja la persuasión interior, la fe. Desde este punto de vista, la greña entre católicos y protestantes resulta incomprensible, puro escolasticismo.

Pues precisamente. Con la escolástica la gracia había cambiado por completo de sentido. Si inicialmente apuntaba al ser de Dios, a su benevolencia, luego se irá escorando hacia la acción de Dios, hacia sus resultados. De referirse a una actitud de Dios pasará a sugerir su eficacia en el hombre. Cierto que esto ya está presente en el concepto de gracia, como acabamos de ver, pero de asentarse en una idea de Dios de la que se siguen unas consecuencias, tenderá a bloquearse en las consecuencias. Todo parece comen- 
zar con la mentalidad gnóstica, según la cual lo divino y espiritual deviene una "fuerza" en el hombre que conoce la revelación ${ }^{23}$, y que en el cristianismo compondrá una línea amplificada con san Agustín, en quien la gracia es una "ayuda" imprescindible de Dios para que el hombre pueda obrar bien ${ }^{24}$. La gracia deja entonces de enfocar a alguien, al Dios favorable, para objetivarse como algo distinto de Él, para cosificarse en sus efectos. La suerte estaba echada, la influencia del doctor de la gracia será inapelable. La furia analítica de la escolástica desmenuzará la gracia al máximo: creada e increada, sanante y elevante, actual y habitual, preveniente y cooperante, suficiente y eficaz. Con este paroxismo elucubrativo, al final nadie sabría muy bien de qué se hablaba cuando aparecía la palabra gracia. Algo así como el queso cuya bondad aumenta con los agujeros: su mayor calidad pedirá un gran hueco, se quedará en nada.

No es de extrañar que la síntesis protestante de solus Deus, sola gratia, sola fide, se sintiese como una brisa fresca y tonificante. Era la recuperación de la esencia bíblica, de la sencillez evangélica, la recapitulación del bálsamo de la salvación regalada. Así, se puede estar muy de acuerdo con la idea luterana de la certeza de salvación implicada en la fe: la fe es confianza en la misericordia de Dios, en su poder favorable. Es certeza salvífica creída, liberadora, aunque no salvación conseguida o vaticinio inamovible. La fe y existencia humanas son variables a pesar de la fidelidad de la gracia divina ${ }^{25}$.

\section{La libertad podrida}

Además de la justificación por la sola fe, como su reverso, el luteranismo se atiene a un segundo principio fundamental: la pecaminosidad humana. La justificación divina resalta muchísimo más al juzgar abrumadora la perversión humana. Pero siendo un acierto inmarcesible el realce de la justificación que se basta a sí misma, la afirmación de lo segundo se ha quedado descolocada, y además de anacronismo reverbera horripilancia.

Sin duda, la salvación es siempre "justificación del impío", pero en la Escritura la impiedad humana queda expresada como constatación existen-

\footnotetext{
23 CONZELMANN 365s; 380s.

${ }^{24}$ Repetido en los escritos antipelagianos, por ejemplo: "si no nos ayuda Dios con su gracia, nadie se convierte a la justicia” (Los méritos y el perdón de los pecados 2,33). Ver LADARIA 159-163.

25 E. JüNGEL, El evangelio de la justificación del impio como centro de la fe cristiana, Salamanca 2004, 283-286.
} 
cial, no como constitución esencial. A lo largo de todos sus libros, de las épocas y culturas que refleja, la maldad del hombre es una firme convicción de la Biblia. La historia de Adán filosofa narrativamente que ya desde el primer momento el primer ancestro incurrió en falta (Gn 3,1ss), versos religiosos lloran: "en la culpa nací, pecador me concibió mi madre" (Sal 51,7), para desembocar en la sentencia paulina: "tanto judíos como griegos están todos bajo el pecado" ( $\mathrm{Rm} 3,10)$. Pero en la mentalidad bíblica, la realidad pecadora del hombre es la descripción de un hecho, no es la definición abstracta de una entidad, como procede la mentalidad filosófica griega. Para simplificar, si la pregunta es ¿el hombre es pecador porque peca o peca porque es pecador?, la Biblia responde con lo primero, desde la experiencia vital, mientras la abstracción supraempírica acude a lo segundo, a la causalidad esencial.

El asentamiento del cristianismo en el mundo helénico lo empezaría a recubrir de gruesa dermis metafísica ${ }^{26}$. Ya en el Nuevo Testamento hay apuntes esencialistas, si bien no se pierde la visión existencial: Pablo y Juan consideran el pecado una magnitud cósmica que condiciona a todo hombre, aunque no olvidan que cada uno ratifica con sus actos dicha fuerza natural ( Rm 5,12; Jn 1,10). Pero platonismo, estoicismo y gnosticismo, popularmente absorbidos como especialización filosófica, ética y religiosa, hacían buenas migas y lo invadían todo. Particularmente, el esquema gnóstico del hombre como chispa divina castigada en la prisión corporal por haber traicionado su origen atraído por la materia pareció idóneo para interpretar el pecado del paraíso. Las teorizaciones existenciales sobre la acción se diluyen, las explicaciones esencialistas previas a la libertad se imponen.

El resultado de la polémica agustiniano-pelagiana cuadró para los siglos posteriores la antropología teológica del cristianismo. Si la teoría de Pelagio se fundamentaba en la integridad de la naturaleza humana, cuya voluntad era capaz de discernir y decidirse por sí sola por el bien, pareció a Agustín que eso vaciaba la redención y anulaba la necesidad de la gracia, suprimía el núcleo de la fe, deleznaba el cristianismo. No podía haber cosa peor. Así que resaltó hasta la desmesura la miseria humana y su total dependencia de la gracia: desarrolló la doctrina del pecado original, el hombre nace como "naturaleza viciada" 27 , es una criatura congénitamente per-

\footnotetext{
26 Sobre esto, R. Bultmann, Teología del Nuevo Testamento, Salamanca 1980, 239-511; P. RICOEUR, Finitud y culpabilidad, Madrid 1969, 682-684; E.R. DoDDs, Paganos y cristianos en una época de angustia. Algunos aspectos de la experiencia religiosa desde Marco Aurelio a Constantino, Madrid 1975.

27 Réplica a Juliano (inacabada) 3,109.
} 
vertida; y se acercó peligrosamente a la predestinación, la humanidad compone una "masa de pecado" apenas rebajada por la intervención graciosa de Dios ${ }^{28}$. Sincero discípulo de Agustín, desgarrado por la impotencia experimentada en su ascesis monacal y por la frivolidad de la Iglesia de su tiempo mercadeando la salvación con indulgencias, Lutero pisó algo más a fondo: el hombre es absoluta corrupción, su voluntad supone una mueca dolorosa, una "libertad esclava", su destino más cierto sin la "imputación extrínseca" de los méritos de Cristo sería la condenación ${ }^{29}$.

Actualmente, superadas las luchas doctrinales de matriz pelagiana y protestante, desfasadas y abstrusas las controversias teóricas sobre la esencia, transmisión, voluntariedad y efectos del pecado original, convendría revisar la antropología cristiana desde la evolución de los dogmas y la ciencia moderna.

Primeramente, lo que a Agustín y a Lutero interesaba realzar era la necesidad de la gracia para la salvación, la imposibilidad de alcanzarla por los propios medios. Ahora bien, para afirmar que la salvación es siempre gracia donada, el núcleo del dogma, no hace falta denigrar la naturaleza humana, revestimiento secundario al servicio de lo nuclear, exaltado entonces aquél por la polémica. La incapacidad humana de salvación es una evidencia creatural, la finitud no puede conquistar por sí sola la infinitud, es innecesario zurrar la badana del hombre para ratificarlo. De lo contrario, recaeríamos en la crítica certera del humanismo ateo: hay que abolir a un Dios que enajena al hombre ${ }^{30}$.

En segundo lugar, la libertad humana sigue siendo una cuestión candente y sin resolver, pero puede abordarse científicamente. Como la teología de la creación no puede prescindir sin descrédito del evolucionismo o del big bang, así tampoco la antropología teológica podrá ignorar las conclusiones de otras ciencias. El problema es que no hay conclusiones unánimes, ni en psicología o biología o sociología ${ }^{31}$. La solución podría entrever-

28 Diversas cuestiones a Simpliciano $1,2,16$.

29 Comentario a los Romanos, prefacio; 4,7; Disputa de Heidelberg 13; De servo arbitrio. Calvino da un paso más, una explicitud que escalofría: "Llamamos predestinación al eterno decreto de Dios por el que ha determinado lo que quiere hacer de cada uno de los hombres. Porque Él no los crea a todos con la misma condición, sino que ordena a unos para la vida eterna y a otros para la condenación perpetua" (Institución de la religión cristiana 3,21).

${ }^{30}$ L. FeUerbaCH, La esencia del cristianismo, Salamanca 1975.

31 Para el psicoanálisis y el conductismo el comportamiento se predice desde condicionamientos físicos y culturales (S. FREUD, Más allá del principio del placer: Obras completas, I, Madrid 1967, 1097-1125; L.F. SKINNER, Más allá de la libertad y la dignidad, Barcelona 1986). Para la psicología cognitiva, en cambio, la libertad es la base de la especificidad humana (A. MASLOW, Motivación y personalidad, Madrid 1991). 
se si fuera posible demostrar experiencialmente acciones libres contra condicionantes adversos, más allá de elucidaciones teóricas de despacho. Pues bien, la vivencia de un psiquiatra vienés, judío en tiempos nazis, prisionero en las circunstancias extremas de los campos de concentración, donde perdió padres ancianos y joven esposa embarazada, lo evidenció superando junto con unos pocos compañeros de infortunio un espanto inconcebible por férrea decisión, frente a la gran mayoría que sucumbió, tal vez más sanos, más jóvenes, más corpulentos, pero con menor fortaleza de ánimo ${ }^{32}$. El testimonio de todos ellos es un monumento irrebatible sobre la realidad humana: dispar y coincidente, capaz de lo mejor y lo peor, tan previsible como inesperada, sin nada escrito y constreñida por su ambiente, una existencia condicionada pero no determinada.

Verdaderamente, la libertad es la contraparte del raciocinio, es aptitud de elección basada en el discernimiento. Lo uno implica lo otro, si aceptamos la mente superior humana, el mismo paquete incluye la libertad. Son las facultades clásicas del alma: inteligencia y voluntad ${ }^{33}$. Desde luego, es una libertad limitada, justamente como lo es la inteligencia, recortada por la finitud, la dependencia social, el egoísmo. Pero por más que uno se sulfure destacando la imperfección de la libertad, ahí también está reconociendo cierto margen de decisión. De este modo, la naturaleza humana no es ni santa ni diabólica, sino más bien neutra, porosa, presionada constantemente por condicionamientos físicos, culturales, psíquicos, desde los cuales se ve forzada a vivir eligiendo. El mal no proviene de la libertad degenerada, sino simplemente de la libertad. Si libertad significa capacidad de elección, en sí misma conlleva la posibilidad de elegir el mal a sabiendas, el pecado. El mal es el lado oscuro de la libertad.

Mantener hoy día la malignidad innata del ser humano no es sólo contrario a la percepción común y científica modernas, a las que recuerda viejos fanatismos. Es también un presupuesto religioso sin objeto, pues la gracia divina se defiende sin ayuda, que además resulta barbárico, aboca al pesimismo existencial y a la predestinación, nada más contrario a la "buena noticia" cristiana.

Así que la célebre expresión luterana de simul peccator et iustus, pecador genético pero declarado justo por Dios en $\mathrm{Cristo}^{34}$, caería por sí sola en su tenor original: ni el hombre es malvado sin su mala intención ni puede saberse agraciado sin ser renovado internamente. La frase es comprensible

\footnotetext{
32 V. FRANKL, El hombre en busca de sentido, Barcelona 2004.

33 ARISTÓTELES, Acerca del alma 411a25.

34 Comentario a los Romanos 4,7.
} 
en su contexto de drama personal y controversia eclesial, pero en sí misma es incluso contraria a la Escritura ${ }^{35}$. Por su parte, justificación y santificación deben ser tomadas como sinónimas, en lo que coincidieron tanto Lutero como Trento, aunque cada cual dándole un significado distinto, forense uno y ontológico el otro ${ }^{36}$. La justificación, la acción de la gracia de Dios, desde la aceptación de fe por el hombre, no puede menos que ser transformadora. En cuanto a la concupiscencia, literalmente "deseo intenso" y teológicamente "inclinación al mal", si tomada en sentido agustiniano se concentra como libido sexual ${ }^{37}$, entonces es un hecho natural, moralmente neutro, que empaña pero no tapa, condiciona pero no elimina la libertad. Si asumida en plan luterano designa el orgullo y la incredulidad, el engreimiento suplantador de Dios, el egoísmo malévolo, sin duda es el peccatum radicale et originale, la fuente de todo pecado ${ }^{38}$, pero entonces no pende de la naturaleza sino de la decisión libre.

\section{La doble hélice}

¿Cuál es la esencia del cristianismo, el núcleo que señala su contribución propia y lo distingue de otras religiones, el centro sobre el que gravita su desarrollo histórico y doctrinal, el gozne sobre el que gira todo? A partir de Lutero, la voz del protestantismo es unánime: la justificación, doctrina por la que "se sostiene o derrumba la Iglesia"39. Sin embargo, antes de la Reforma, en los primeros tiempos cristianos, desde luego más ejemplares, y en los muchos siglos de evolución posterior, también durante la minuciosidad analítica escolástica, tal cuestión parece secundaria. Y después, a partir del racionalismo de la Ilustración, los distintos escritos que han ido abordando el tema críticamente llevan a desmentir que ésta sea una cosa $\tan$ clara 40 .

35 Así Wilckens II,146s (él también en MAfFeis 295). Por el contrario, la defiende JÜNGEL 253-263.

36 Catecismo breve II,3; DENZINGER-HÜNERMANN 1528.

37 Los méritos y el perdón de los pecados 1,57; El matrimonio y la concupiscencia 1,16; 2,42 .

38 Comentario a los Romanos, prefacio; 4,7; 7,7; Disputa de Heidelberg 7s.

39 Citas de la famosa sentencia de Lutero en JüNGEL $37 \mathrm{~s}$.

40 B. FORTE, La esencia del cristianismo, Salamanca 2002, 159-183, recensiona brevemente otras obras con el mismo título: Feuerbach, Harnack, Guardini, Hamilton, todas centradas en el amor. JÜNGEL 39-61 critica a Fichte, Wrede y Schweitzer por desautorizar la justificación y se enfada porque incluso Barth parece relativizarla. 
Para atinar con la médula de la fe cristiana habrá que acudir primeramente a la predicación de Jesús, puesto que para todos los fieles en todo tiempo es evidente que Jesucristo compone la clave central del cristianismo. Pues bien, es ya un dogma científico de la exégesis bíblica moderna que el reino de Dios constituye el meollo de la actividad pública de Jesús, en sus palabras y acciones, expresión que quiere proclamar el poder favorable de Dios, el desbordamiento de su gracia generosa, la manifestación de su salvación irrevocable 41 . "El tiempo se ha cumplido y el reino de Dios está cerca; convertíos y creed la buena noticia" (Mc 1,15). Este anuncio decide la aparición sorpresiva de Jesús, a decir de Marcos, el evangelista más antiguo. Esto es, indica el por qué de su entrada en escena, en la que destaca que la espera del pueblo ha llegado a su término: la salvación ya está aquí, alrededor. Acota también el foco de su misión, que irá explanando luego a través de sus curaciones de la enfermedad, sus enseñanzas parabólicas, su perdón de los pecados, su compasión hacia los desfavorecidos: la benevolencia de Dios se muestra como algo absoluto, definitivo.

Es una manera nueva de interpretar a Dios, dispersa en el Antiguo Testamento y ahora destilada. ¿Podemos parafrasearla? Semejante atrevimiento no nos lleva más allá de la tautología, a imágenes ya condensadas en el Nuevo Testamento. Estaría exclamando: Tenemos que saber y creer y vivir y gozar que Dios es amor incondicional (Mt 5,44s), padre cariñoso (Lc 12,22ss), perdón constante (Mt 18,21s), sensible a la desgracia (Lc 6,20ss)... Dios está de nuestra parte. Todo ello galvaniza, se transforma en un impulso, se exterioriza en el modo de vivir: convertíos, volved al Dios de la gracia, alegraos.

¿En qué consiste más concretamente dicha conversión? Cuando preguntan a Jesús por el mandamiento principal, responde uniendo dos: amarás al Señor tu Dios y amarás al prójimo como a ti mismo (Mc 12,30s). Estos dos mandatos son uno y compendian toda la Escritura, y podrían sintetizarse un poco más y quedarse en el amor al hermano. Efectivamente, el amor al prójimo es el solo criterio de validación del amor a Dios puesto que éste es en sí espiritual, incomprobable. Así lo entendieron los primeros cristianos en sus diversos escritos y corrientes: el amor al prójimo resume la Ley y los profetas (Gál 5,14; Mt 22,40) y la enseñanza de Jesús (Jn 13,34), es la verdadera Ley (St 2,8), sin él de nada sirve la fe (1Cor 13,2), pues no se puede amar a Dios, a quien no se ve, si no se ama al hermano, a quien se ve $(1 \mathrm{Jn} 4,20)$. La identidad del amor a Dios y al prójimo es tal vez la apor-

41 Ver T. Marcos, Semilla del Reino. Sobre la continuidad entre el Reino de Dios y la Iglesia: Estudio Agustiniano 30, 1995, 59-70. 
tación más original del mensaje de Jesús: el precepto del amor a Dios se realza en el Antiguo Testamento (Dt 6,5) y el consejo del amor al otro, incluso enemigo, colorea a religiones orientales -taoísmo y budismo- y al estoicismo ${ }^{42}$. Significa que no puede haber religión sin ética, que no es posible la adoración a Dios sin conciencia de fraternidad y lucha por la justicia. Si hiciéramos caso, nuestros actuales y eternos problemas de guerra santa y odio religioso quedarían conjurados como la enfermedad con la vacuna.

Así pues, la esencia del cristianismo desde la enseñanza de Jesús es doble. De un lado, la confianza en la salvación de Dios, en la bondad de Dios, que Dios es amor (1Jn 4,8). Lo que arrastra por su propia dinámica, de otro lado, al amor al prójimo, sentir dentro el amor incondicional de Dios es vivir desde el amor de Dios, amar incondicionalmente. El amor de Dios y el amor al prójimo son los dos ejes que aglutinan el entramado dogmático, ético y litúrgico de la fe cristiana, ejes entrelazados, como enredados entre sí, al modo de la estructura de la molécula ADN de la vida, la doble hélice, de modo que en sus ramificaciones cada uno busca y anticipa y sostiene al otro, como la adenina replica timina y la guanina exige citosina. Por una parte, creer en el amor inmerecido de Dios es traspirarlo, reflejarlo en la alegría y la caridad. Y por otra, el amor, respeto y defensa de los demás, para los cristianos incluye la fe en Dios, a sus sustentadores les puede considerar cristianos aunque no lo sean ${ }^{43}$; o de todos modos supone una confianza de sentido, una esperanza metempírica, sea cual sea: es difícil persistir de otra manera en el trabajo altruista, sobreponiéndose a ingratitudes y fracasos, como bien saben comunistas y misioneros.

Pero la esencia del cristianismo no se asienta sólo en el mensaje de Jesús, sino también en el significado de Jesucristo captado por la Iglesia, pues eso es precisamente cristianismo. Dicha esencia parece entonces deslizarse un poco, no va a consistir tanto en la enseñanza misma de Jesús, aunque la incluye, cuanto en el alcance total de su persona, revelado plenamente sólo tras la pascua. Pero semejante deslizamiento es más aparente que real. El centro de la fe cristiana va a ser ahora el kerigma (1Cor 15,3s), el anuncio de la eficacia salvífica de la muerte y resurrección de Jesucristo. La muerte de Jesús es redentora, liberadora, muestra la misericordia inmensa de Dios por el hombre, pues a pesar de ser nosotros pecadores y Jesús su "Hijo amado" (Mc 1,11), Dios "lo entregó por todos nosotros"

\footnotetext{
42 J. GNILKA, Jesús de Nazaret. Mensaje e historia, Barcelona 1993, 276-303.

43 Es lo que pretendía significar Rahner con una polémica expresión suya, Los cristianos anónimos: Escritos de Teología, 6, Madrid 1969, 535-544.
} 
( $\mathrm{Rm} 8,32$ ), revelando en ello su favor insuperable. Y su resurrección manifiesta la reivindicación definitiva que de él hace Dios, no abandonándolo a la muerte sino exaltándolo en la gloria, de la que nosotros participaremos si creemos y vivimos en Cristo (1Cor 15,20-22). Así que en realidad, la muerte y resurrección de Cristo no son sino la concreción de la primigenia salvación de Dios predicada por Jesús, la plasmación del reino de Dios, que se ha anticipado plenamente en su historia.

El reino de Dios jesuano y la resurrección de Cristo dicen lo mismo que la justificación paulina, a fin de cuentas la victoria rompedora del poder favorable de Dios. La condición que pone Pablo para asumirla es la fe, y la condición de Jesús es la conversión, pero ya hemos reseñado que lo mismo da que da lo mismo, que fe y caridad se autoimplican.

¿Qué decir entonces de la fuerte convicción reformada sobre la justificación como núcleo fundamental del cristianismo, "centro del centro de la fe cristiana"44, en que se apuntala o desploma la Iglesia? Dado que justificación significa lo mismo que reino de Dios o salvación de Dios, puede suscribirse muy bien su dogma fundante sin problemas, de modo que la justificación subsuma el mensaje evangélico de la cercanía magnánima de Dios y sirva de criterio insustituible de identificación de lo cristiano. Ahora bien, en su sinonimia, lo dicho debe valer también al contrario, es decir, la proclamación del amor de Dios será también autosuficiente como summum del cristianismo y podrá integrar la fe en la justificación sin necesidad de su explicitud. Y además, el reino de Dios o la justificación es sólo una hélice que por sí misma recrea su gemela del amor al prójimo en el genoma de la fe cristiana, de modo que también se puede hablar simplemente de la fraternidad humana como corazón del cristianismo ${ }^{45}$, pues ésta encierra en sí la confianza en la paternidad y ternura de Dios. Si hay que reconocer el acierto de Lutero y sus seguidores por la insistencia en la salvación como regalo sobrenatural, como santificación y sola gratia, no es menos cierto advertir que ello conlleva de por sí el esfuerzo humano por la caridad y la justicia, cosa siempre algo trascordada en la esfera protestante por su prejuicio sobre la radical maldad humana.

\footnotetext{
44 JÜNGEL 35.

45 Para los no creyentes es el sello de calidad del cristianismo. DoDDs 179: "Los cristianos eran miembros unos de otros en un sentido mucho más que formulario. Pienso que esta fue una causa importante, quizá la más importante de todas, de la difusión del cristianismo". Y cita a Festugière (nota 112): "De no haber sido por esto el mundo seguiría aún pagano, y el día en que esto se acabe el mundo volverá a ser pagano".
} 


\section{TERMINAR POR EL PRINCIPIO}

El motivo de la rebelión de Lutero fue eminentemente religioso, pero el éxito y perduración del protestantismo ha sido sobre todo político. Evidentemente, hay una continuidad entre uno y otro, pero también se da una especie de escalón entre ambos, como una falla en la línea que les une, que supone por eso distinta base. El mismo Lutero pasó de un nivel al otro ${ }^{46}$.

Sobre lo primero, Lutero comenzó siendo monje agustino, no lo olvidemos, de la rama observante, y durante unos quince años sus principales preocupaciones fueron el trabajo encomendado, la ascesis, la oración, la espiritualidad, todo en la más estricta ortodoxia de su tiempo y congregación. El comienzo de la ruptura, como es notorio, halló pie en 1517 por la cuestión de las indulgencias, asunto en el que Lutero protestaba por la degradación económica que implicaba y en el que demandaba depuración espiritual. De lo que se trataba era de la conversión, por lo que para los vivos la penitencia es preferible a las indulgencias, pues "por las indulgencias uno no se hace mejor, tan sólo se libra mejor de las penas", mientras los difuntos "se liberan de todo por la muerte y están ya muertos a las leyes canónicas"47, no necesitan créditos eclesiales, quedan desnudos ante la misericordia de Dios. Y lo que constituyó el origen de la Reforma, la célula de su nacimiento y savia de su expansión, la justificación por la sola fe, fue una experiencia mística en torno a la misma época. Enfrascado en la preparación de sus lecciones universitarias sobre la Carta a los Romanos y siempre atormentado por la salvación del alma, le subyugó una revelación merodeando alrededor de Rm 1,17. "Odiaba la expresión 'justicia divina', en virtud de la cual Dios es justo y castiga a los pecadores e injustos (...). Hasta que comencé a darme cuenta de que la justicia de Dios no es otra que aquella por la cual el justo vive del don de Dios, es decir, de la fe (...). Desde aquel instante, cuanto más intenso había sido mi odio anterior hacia la expresión 'la justicia de Dios', con tanto más amor comencé a exaltar esta palabra infinitamente dulce. Así, este pasaje de Pablo fue en realidad mi puerta del cielo"48. La terrible contradicción semántica que encerraba la justicia de Dios, que podía insinuar una cosa y su contraria, tanto reprobar

46 Para lo que sigue, J. Delumeau, El caso Lutero, Barcelona 1988; H.A. Oberman, Lutero. Un hombre entre Dios y el diablo, Madrid 1992; T. EGIDO, Las reformas protestantes, Madrid 1992.

47 Las 95 tesis $44 ; 13$.

48 Prólogo a 'Obras completas' latinas. 
como salvar, explica el avatar de Lutero, que desde sus dudas personales pasó de la postración a la euforia.

Naturalmente, toda subversión doctrinal, por religiosa que nazca y desee permanecer, no puede dejar de incidir en la estructura que sostiene lo criticado. Así Lutero, en sus primeras y centrales obras de reforma, todas del año 1520, cuando la confrontación se acelera, comienza a vislumbrar las consecuencias de su asonada. En El papado de Roma habla de una verdadera Iglesia espiritual más que institucional; desde $A$ la nobleza cristiana de la nación alemana desecha el pretendido poder civil y sobre la Biblia que se arroga el papa; en La cautividad babilónica de la Iglesia considera los sacramentos como instrumentos de control eclesiástico más que expresiones de salvación; y finalmente, La libertad del cristiano ensalza el poder interior del creyente, no sometido a nada ni a nadie. El trasfondo rezuma por todos los poros un deseo de liberación colectiva y personal respecto del poder romano, el inicial impulso místico va arrastrando al rechazo de todo andamiaje impositivo de base espiritual.

Cuando la ruptura se hizo oficial, con la excomunión de la Iglesia y la proscripción del Imperio en 1521, el afianzamiento y difusión del movimiento de reforma iniciado por Lutero fue imparable, sorprendente en su rapidez. La clave estuvo en el apoyo de los poderes civiles: los regentes de muchas ciudades centroeuropeas, los príncipes territoriales alemanes, los reyes escandinavos y británicos. ¿Por qué se decantaron tan entusiastas por la palabra aislada e innovadora de un fraile ignoto de una humilde universidad de una pequeña población de las profundidades de la cristiandad? Elemental, querido chato: el poder político y la prestancia económica son tentaciones irresistibles, y si se dan juntos debe de ser hasta pecado venial. Ediles, nobles y monarcas se encontraron en la sublevación con todo el poder en sus ámbitos, libres de interferencias eclesiales del papa, obispos o legados; quedaban además con las posesiones inmuebles de monasterios suprimidos y obispados secularizados; y también con las más muebles, pues los dineros otrora captados por la estructura católica a través de indulgencias, sufragios y donaciones, dado que seguirían buscando dueño al mantenerse el requerimiento de protección espiritual, podían ahora ser derivados a los nuevos mandatarios socio-eclesiales.

Por supuesto que hubo más razones para el apoyo generalizado en amplias zonas del centro y norte de Europa a la novedad confesional: el malestar hacia la concentración de poder y la corrupción continua del papado, los anhelos y angustias de las conciencias de la época respecto la salvación y la muerte, el humanismo ansioso de autonomía espiritual y contacto per- 
sonal con la Biblia, la divulgación masiva de estas ideas a través de la recién nacida imprenta, el incipiente nacionalismo germánico... Pero el aglutinante de toda la desazón de fondo, el cristalizador de los aires de oposición no podía ser sino la autoridad civil. Y cuando la política se junta con la religión, aquélla suele servirse de ésta y no al revés, aunque lo parezca; pues cuando la religión se sirve de la política es que aquélla se ha trocado en política travestida de religión, con lo que se vuelve al principio.

Existió por tanto una fuente religiosa en el surgimiento de la Reforma luterana, prístina y principal, que la alimenta y revitaliza, y un sostenimiento político de la misma, posterior y accesorio, derivado de pretensiones autonomistas socio-económicas respecto a Roma, que la posibilitó sirviéndola de cauce y difusor, anclándola en la estructuración social. Entre ambos, a modo de engarce asimismo secundario, se organizarán las comunidades protestantes, caracterizadas por la presencia directiva de la autoridad civil y por autodeterminaciones de conciencia frente al poder clerical que hasta entonces dominara completamente.

Pues bien, en lo principal, en la justificación por la fe, reconocimiento de la eficacia de la gracia de Dios y aceptación comprometida de la salvación como regalo sobrenatural, resulta que no hay gran diferencia entre católicos y reformados, incluso habría que decir que siempre han coincidido esencialmente, más allá de formulaciones polémicas. En lo más crudo de la controversia, diez años después del comienzo de la ruptura, en 1530, la fórmula luterana de la Dieta de Augusta supo distinguir lo medular y lo adyacente e intentar un principio de acuerdo. Después de exponer lo primero, entre lo que naturalmente se encuentra la justificación por la fe, "que debe ser obligatoriamente la doctrina principal de la Iglesia", se concluye: "Este es el resumen de la doctrina que enseñamos. Como puede verse, no hay nada que esté en desacuerdo con las Escrituras o con la Iglesia universal o con la Iglesia romana. (...) Toda la diferencia estriba en ciertos abusos, poco numerosos, que desprovistos de una autoridad bien definida, se han deslizado en las Iglesias"49. Y más tarde, con el concilio de Trento (1545-1563), cuando la distancia entre ambos ya era infranqueable, persiste indiferente a las acritudes el acuerdo en lo sustancial. Así dice el canon 1 sobre la justificación: "si alguno dijere que el hombre puede justificarse delante de Dios por sus obras, realizadas por las fuerzas de la humana naturaleza o por la doctrina de la Ley, sin la gracia divina por Cristo Jesús, sea anatema"50.

${ }^{49}$ Confessio Augustana 20; 21.

50 DENZINGER-HÜNERMANN 1551. 
Las aristas divergentes, de raíz libertaria frente al omnímodo brazo romano, tanto en su vertiente social como intraeclesial, de un lado no dejan de ser cuestiones derivadas de lo central concordante, y de otro podríamos decir que han ido siendo limadas por el tiempo y la mentalidad.

En cuanto a la injerencia política de la Iglesia en la sociedad, desde el Vaticano II se reconoce como legítima la "autonomía de la realidad terrena, que las cosas creadas y la sociedad misma gozan de propias leyes y valores que el hombre ha de descubrir, emplear y ordenar"51, en plata, la independencia de la sociedad civil respecto de las normas eclesiales, el derecho de aquélla a regirse según sus principios, pensados para una convivencia pluralista, capaz de armonizar la vida de creyentes y no creyentes. Con ello, una de las reivindicaciones puntales de la Reforma ha sido no ya lograda sino incluso mejorada, pues el protestantismo desembocó en la misma injerencia anterior al revés, la del poder civil en la Iglesia, ligando a fin de cuentas fe religiosa y comunidad política, en exacto paralelismo a los católicos. Eran momentos de identidades excesivas entre conciencia y convivencia, de la religión como vector de cohesión social, como atestigua el famoso lema de la paz de Augusta de 1555, cuius regio eius religio. La defensa vaticana de la libertad religiosa, "que los hombres exigen para el cumplimiento de su obligación de rendir culto a Dios la inmunidad de coacción de la sociedad civil", que a nadie se debe prohibir u obligar ninguna opción confesional, el Estado debe ser exquisitamente neutral, favorecedor de toda elección espiritual, "pues la verdad no se impone de otra manera que por la fuerza de la misma verdad, que penetra suave y a vez fuertemente en las almas" 52 , expresa la llegada de nuevos tiempos. La acogida de estos idearios por la Iglesia se cuenta justamente entre los mayores signos de aggiornamento que ha supuesto el concilio. La Iglesia ya no impone sus reglas a ninguna sociedad moderna, aunque pueda seguir siendo muy influyente, y en contrapartida pide libertad de acción religiosa en medio de la sociedad.

Respecto a la injerencia religiosa del clero en la conciencia, la evolución cultural de Occidente en pro de la autonomía individual, base de las democracias y la revolución de las costumbres del siglo XX, parece tan irreversible como una cima del espíritu. Parte de la descristianización que vivimos, enmarcada en la crisis general de las instituciones, se debe a la emancipación de los individuos, que toleran malamente dictados autoritarios. La revitalización de las Iglesias es imposible sin el reconocimiento de la libertad de conciencia de sus integrantes, cosa que teóricamente el cristianismo ha

51 Gaudium et spes 36.

52 Dignitatis humanae 1. 
resaltado de modo fundacional (1Jn 2,27), libertad que habrá de compaginarse con la eclesialidad del ser cristiano (y desde ahí acoger Magisterio y Tradición), pues un desequilibrio individualista deshace la eclesialidad y unidad de la fe, poniendo en peligro su misma subsistencia. El rescate de la Escritura para el creyente, sin tutelas de maternidad posesiva como ha usado la Jerarquía, otra reivindicación luterana y otro signo de actualización del Vaticano II, serviría de puente y argamasa entre individuo y comunidad.

Así pues, si las disonancias de segundo orden sobre la emancipación de la libertad individual y social respecto de la Jerarquía han ido confluyendo o desapareciendo por sí solas, y si en la centralidad de la justificación catolicismo y protestantismo han estado más unidos de lo que nunca han pensado, ¿puede saberse por qué se mantiene todavía cerrilmente la separación? Sola gratia como aclamación primordial de que la salvación es donada, sola fide en cuanto pleitesía a la responsabilidad insustituible de cada creyente, sola Scriptura como reverencia incambiable hacia la autoridad mayor de la revelación (no reñida con autoridades eclesiales secundarias), son programas que resumirían admirablemente el engranaje ideal de la religión cristiana.

Los aspectos divisorios subalternos que todavía restan podrían resumirse en "la doctrina sacramental y la doctrina del ministerio eclesial" 53, y no debieran ser insuperables. Y un rasgo básico separador, para Lutero el trasluz de la justificación por la fe, esto es, la absoluta corrupción e incapacidad de la naturaleza humana para el bien, bien podría considerarse un peaje cultural de la encrucijada entre la Edad Media y Moderna que ya no es necesario pagar, estando como estamos en otro milenio nada menos. Aquélla fue una época condicionada por desesperaciones existenciales y sobrenaturales, por la inermidad ante la omnipresencia de la insania, la muerte, el demonio y la condenación. El negativismo antropológico luterano fue el modo de agudizar la confianza en la potencia de la salvación divina, que superaría con creces la desconsoladora degeneración humana. Pero esta solución gotea ambigüedad, puede resultar también contraproducente: abandonando al hombre pasivamente a la misericordia de Dios porque su condición es irredentamente mala, no sólo se denigra su dignidad y se nutre una psicología morbosa y autodestructiva ${ }^{54}$, sino que se arriba al Dios arbitrario y demente de la predestinación, cosa que los reformados intentaron .

53 Afirmación de Pannenberg (MAFFEIS 301).

${ }^{54}$ A. ELLIs, Razón y emoción en psicoterapia, Bilbao 1980, 121-132. 
bien pronto reinterpretar o rechazar ${ }^{55}$. La apología de la gracia de Dios no necesita ni siquiera el apoyo de la podredumbre humana.

Por tanto, y en resumidas cuentas, la actual división entre la Iglesia católica y los movimientos reformados, así como la anterior con los ortodoxos, no deja de ser sino un anacronismo pertinaz. Algo tan explicable desde las circunstancias y extremismos de un tiempo pasado, como inexplicable desde la situación cambiada y tolerante del tiempo presente. Como en el pecado está la penitencia, según la sabiduría popular, el cristianismo continuará sufriendo el descrédito de la división mientras las Iglesias cristianas se empeñen en justificarla. De nuevo la justificación... pero humana, demasiado humana.

Tomás MARCos MARTíneZ, OSA Estudio Teológico Agustiniano

VALLADOLID

55 Ya con Melanthon (DelumEAU 67; 81). 